\title{
Beyond proof of concepts for ideal cardiac regenerative therapy
}

\author{
Naoki Mochizuki, MD, PhD, ${ }^{\mathrm{a}}$ James T. Pearson, $\mathrm{PhD},{ }^{\mathrm{b}}$ and Soichiro Kitamura, $\mathrm{MD}, \mathrm{PhD}$
}

\author{
From the Departments of ${ }^{\mathrm{a} C e l l}$ Biology, ${ }^{\mathrm{b}}$ Cardiac Physiology and ${ }^{\mathrm{c}}$ Cardiac Surgery, National Cerebral and Car- \\ diovascular Center Research Institute, Osaka, Japan. \\ Disclosures: Authors have nothing to disclose with regard to commercial support. \\ Received for publication April 23, 2017; accepted for publication May 5, 2017; available ahead of print June 20, \\ 2017. \\ Address for reprints: Soichiro Kitamura, MD, PhD, National Cerebral and Cardiovascular Center, 5-7-1 Fujishir- \\ odai, Suita, Osaka 565-8565, Japan (E-mail: skitamur@hsp.ncvc.go.jp). \\ J Thorac Cardiovasc Surg 2017;154:964-5 \\ $0022-5223 / \$ 36.00$ \\ Copyright (c) 2017 by The American Association for Thoracic Surgery \\ http://dx.doi.org/10.1016/j.jtcvs.2017.05.015
}

Prognosis of patients with heart failure (HF) is as low as that of patients with cancer. ${ }^{1}$ Patients with HF who are resistant to conventional drug therapy require heart transplantation or left ventricular assist devices because of worsening HF. However, not all of them can receive hearts from donors because of the limited number of donors and contraindications. Therefore, alternative and efficient therapy in addition to conventional therapy must be realized in the clinical field before heart replacement is required. Regeneration of hearts has become the topic during the past 2 decades.

The study by Shudo and colleagues ${ }^{2}$ in this issue of the Journal has proved the concepts of a potential therapy using 2-layered cell sheets consisting of mural cells and endothelial progenitor cells (EPCs) to preserve myocardial function after ischemic insults. The novel concept of the present study is that therapeutic angiogenesis might be accelerated by blood vessel-constituting cells, endothelial cells, and mural cells. To attain this goal, the authors differentiated vascular smooth muscle cells (SMCs) from mesenchymal stem cells (MSCs) and added these cells as the second layer cells in addition to the first layer of EPCs. They confirmed an increase in blood vessel density and an improvement of cardiac pump function in rats with myocardial infarction treated with the 2-layered cell sheets. Therefore, the proof of concept (POC) was supported by the present data. We reported that MSC sheets can regenerate the heart with scar tissue. ${ }^{3}$ In addition to our report, Golpanian and colleagues ${ }^{4}$ proved the usefulness of MSCs or other progenitor cells for regeneration of the hearts. A new approach using differentiated SMCs from MSCs might be a new modality of cardiac regenerative medicine. However, the fact that a 2-layered cell sheet with SMCs and EPCs is superior to a monolayered MSC sheet is not comparatively demonstrated. The results of 2 studies ${ }^{2,3}$ showed similar results in terms of restoration of left ventricular function and wall thickness.

To regenerate the heart, there are several approaches: injection of stem cells into the myocardium or through

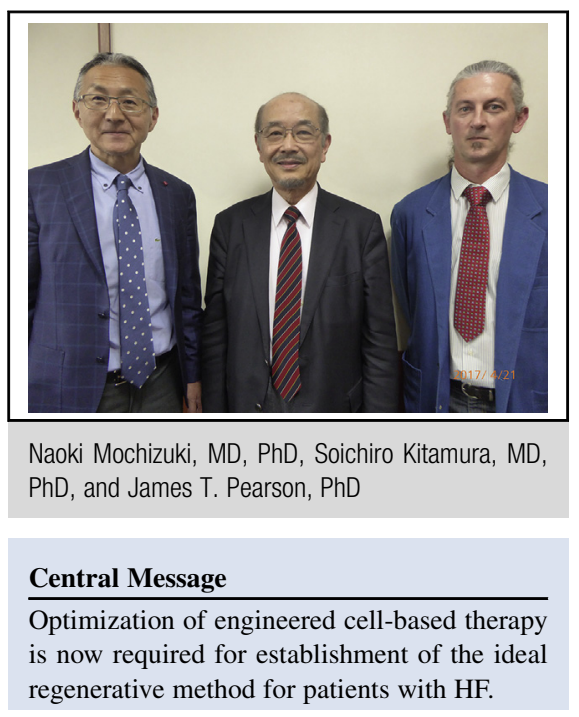

See Article page 955

coronary arteries, implantation of scaffold to accelerate the endogenous recovery system, and cell-sheet. ${ }^{5-7}$ In terms of stem cell transplantation, it is unclear which type of stem cells or their differentiated cells is the best for implantation or whether a combination of stem cells is superior. There are so many materials for scaffolds, such as polythene glycol-hydrogels and polymer nanofibers. Moreover, cell sheets can be produced as a single layers or multilayers. Embryonic stem and inducible pluripotent stem cells (iPSC) have been used to improve the cardiac function of impaired hearts. ${ }^{8}$ Clinical trials using stem cells have demonstrated the contribution of stem cells to prevent remodeling of the heart during and after acute myocardial infarction. $^{9-11}$ Prevascularized sheets consisting of differentiated myocardial and vascular cells from the stem cell could be used as a new method. Optimization of cardiac differentiation of iPSC and industrialization of iPSC must be necessary to render the iPSC useful in the real clinical field. ${ }^{12,13}$ Moreover, it remains unclear how stem cells can work for chronic HF. Given the number of strategies, materials, and combination of cell types (MSCs, residential stem cells, and embryonic stem/iPSC), there are even more POCs at present. What is the best cell combination for the multilayered cell sheet? The present work proved the usefulness of vascular cell sheets. 
We think that the number of POCs is enough for optimizing the regenerative therapies for impaired heart function. It is time now for the physician scientists to decide the best strategy for cardiac regeneration. We need studies to compare the previous POCs and ongoing POCs, and decide the best strategy. Otherwise, the number of POCs might increase endlessly, although the practical therapy for patients with cardiac disease remains unsettled and unproved. The researchers who aim at cardiac regeneration must accelerate further steps to make the preclinical results beneficial for patients. Cooperative study groups as described in this article can contribute to differentiate the POC articles into a well controlled, prospective, and randomized clinical study to evaluate the safety, clinical benefits, and cost-effectiveness of the cell-based therapies for conclusive evidence of cell therapy. Again, although there have been many clinical trials of cell therapy, the results are still conflicting ${ }^{14}$ and none of them has become a standard therapeutic modality for acute myocardial infarction or the resulting chronic heart failure.

\section{References}

1. Askoxylakis V, Thieke C, Pleger ST, Most P, Tanner J, Lindel K, et al. Long-term survival of cancer patients compared to heart failure and stroke: a systematic review. BMC Cancer. 2010;10:105.
2. Shudo Y, Goldstone AB, Cohen JE, Patel JB, Hopkins MS, Steele AN, et al. Layered smooth muscle cell-endothelial progenitor cell sheets derived from the bone marrow augment post-infarction ventricular function. J Thorac Cardiovasc Surg. 2017;154:955-63.

3. Miyahara Y, Nagaya N, Kataoka M, Yanagawa B, Tanaka K, Hao H, et al. Monolayered mesenchymal stem cells repair scarred myocardium after myocardial infarction. Nat Med. 2006;12:459-65.

4. Golpanian S, Wolf A, Hatzistergos KE, Hare JM. Rebuilding the damaged heart: mesenchymal stem cells, cell-based therapy, and engineered heart tissue. Physiol Rev. 2016;96:1127-68.

5. Jackman CP, Shadrin IY, Carlson AL, Bursac N. Human cardiac tissue engineering: from pluripotent stem cells to heart repair. Curr Opin Chem Eng. 2015;7; 57-64.

6. Taylor DA, Sampaio LC, Gobin A. Building new hearts: a review of trends in cardiac tissue engineering. Am J Transplant. 2014;14:2448-59.

7. Feric NT, Radisic M. Strategies and challenges to myocardial replacement therapy. Stem Cells Transl Med. 2016;5:410-6.

8. Coulombe KL, Bajpai VK, Andreadis ST, Murry CE. Heart regeneration with engineered myocardial tissue. Annu Rev Biomed Eng. 2014;16:1-28.

9. Hao M, Wang R, Wang W. Cell therapies in cardiomyopathy: current status of clinical trials. Anal Cell Pathol (Amst). 2017;2017:9404057.

10. Liebson PR. Stem-cell angiogenesis and regeneration of the heart: review of a saga of 2 decades. Clin Cardiol. 2015;38:309-16.

11. Doppler SA, Deutsch MA, Lange R, Krane M. Cardiac regeneration: current therapies-future concepts. J Thorac Dis. 2013;5:683-97.

12. Yamakawa $H$, Ieda M. Strategies for heart regeneration: approaches ranging from induced pluripotent stem cells to direct cardiac reprogramming. Int Heart J. 2015;56:1-5.

13. Denning C, Borgdorff V, Crutchley J, Firth KS, George V, Kalra S, et al. Cardiomyocytes from human pluripotent stem cells: From laboratory curiosity to industrial biomedical platform. Biochim Biophys Acta. 2016;1863(7 Pt B): $1728-48$.

14. Assmus B, Dimmeler S, Zeiher AM. Cardiac cell therapy. Lost in meta-analysis. Circ Res. 2015;116:1291-2. 